\title{
Competences of Industry 4.0: Is the Leadership Important in the Food Service Industry?
}

\author{
Ana $\mathrm{A}^{1}$, Vina Dwiyanti ${ }^{1}$, Ellis E Nikmawati ${ }^{1}$, Sri Subekti ${ }^{1}$, Dewi Eka Murniati ${ }^{2}$ \\ ${ }^{1}$ Study Program of Technology and Vocational Education Post-Graduate School of Universitas Pendidikan Indonesia \\ ${ }^{2}$ UniversitasNegeri Yogyakarta, \\ ana@upi.edu
}

Keywords: Leadership, Vocational Education, Food Service Industry

\begin{abstract}
This study discusses the competence of vocational education students in preparing themselves to enter the workforce. Prospective workers need to prepare themselves with various food service industry qualifications. Amid the 4.0 industrial era, competition between humans and robots is getting tougher. Hundreds of workers in Germany were dismissed for not meeting the qualifications in 2014, April 2019 France has dismissed 1,600 workers and replaced them with robots. For the world of education that focuses on meeting industry needs such as vocational education is a challenge. This research method is a literature review by collecting various references from the results of previous studies that are relevant to the topic of this research and then selected according to needs and analyzed in depth to find answers to this research question. The focus of this research is on the innovation of the competence of food service industry workers needed in the industrial era 4.0. The results of this study are in the form of tracing competencies not possessed by robots and superior humans in them. Leadership is the answer to this problem, leadership is not owned by robots. But the priority for workers in the food service industry who are required to work effectively, efficiently, collaboratively, innovatively and excellently. Preparation of leadership competencies is the capital of vocational education students as prospective workers in meeting the needs of the food service industry.
\end{abstract}

\section{INTRODUCTION}

The food service industry has many demands for workers to be able to provide excellent service for consumers (Costa et al., 2017; Mersha \& Adlakha, 1992). Providing excellent service to the workers must have social skills competencies in this industrial 4.0 era (Ramle \& Rohana, 2012). Working in the food service industry requires workers to have good leadership in organizing various existing jobs (Bauer, Hammerle, Schlund, \& Vocke, 2015). Leadership has a lot of relevance to the various needs of the food service industry (Cichy \& Cook, 1991). However, the current reality, the fulfilment of leadership of workers in the food service industry is still very lacking (Anne, 2015; Bauer et al., 2015).

In the midst of industry 4.0 which demands a variety of employee competency innovations, this phenomenon has occurred and displaced 238 out of 100 employees in Germany (Qin, Liu, \& Grosvenor, 2016) and 1,600 workers in France have been replaced by robots (Reeve, 2016). So, this is a concern for vocational education as an institution and students to prepare themselves so that their role will not be shifted by robots in the industry 4.0 era (Sanders, Elangeswaran, \&Wulfsberg, 2016).

The focus of this study looks at how important leadership is for workers who are in the food service industry. Because in this case the competition of workers is not only with fellow humans as workers. At present, the food service industry has presented robots as workers who are considered more effective, efficient and low cost compared to hiring humans as workers.

\section{METHODS}

This research method is divided into two main parts, namely the search and sorting phase and the data analysis stage. This research is limited to leadership topics in the food service industry. Then further review of this topic refers to empirical findings. The first step is to search and sort electronic databases using the keywords of leadership in vocational education and the food service industry. This electronic database is used as a reference for research obtained from ERIC, Tandfonline, Encyclopedia Special of Education and research gates. 
The next stage is the data analysis stage. Where the database has been collected and sorted and then analyzed according to the purpose of writing this literature review. Each article is read, analyzed and summarized by paraphrasing the research method, results and/or discussion according to the needs of writing this literature review study. This is done repeatedly for all databases that have been owned and in accordance with the topic of this research topic.

\section{RESULTS AND DISCUSSIONS}

\subsection{Competence of Food Service Industry Workers}

In 2018, Indonesia was ranked 9th with the highest tourism growth in the world version of the World Travel \& Tourism Council (WTTC) (Antara News, October 2018). The growth of the tourism sector is directly proportional to the industries in it, including the food service industry. From 2013 to 2018, there was an increase in the number of workers working in the tourism sector. In 2013 the number of workers in the food service services sector amounted to 7.08 million people and in 2018 amounted to 10.18 million people. In 2013 the contribution of the tourism sector to the national workforce reached $8.98 \%$ of the total national workforce. When compared with 2013 , where at that time the labour force in this sector was at 7.02 million workers, the recorded growth achieved by this sector's workforce was $45.01 \%$ in 2018. Seeing this growth, the workers will be required to meet the competency qualifications required by the food service industry (Gerald, 2014). Competence of workers must be able to meet the demands of changing labour market needs with very rapid changes in technology, ways of working, demands of customer tastes, social, economic and cultural environments both nationally and internationally.

The food service industry has special qualifications for graduates of Vocational Education which are included in levels II and III (BNSP, 2017). The qualifications of food service industry in level II and III for graduates of VOCATIONAL EDUCATION are divided into level II: Handling, Steward, Waiter, Baker, Pastry Cook, Cook Helper, while level III: Cook, Captain Waiter, Assistant Chief Steward, Captain F \& B, Captain Baker / Chief Baker, Bartender. These various core competencies and special competencies according to the level II and III certification qualifications are very closely related to social skills which are one of the needs of the Food service Services Industry that will be increasingly sought, so that these competencies must be fulfilled by every graduate of Vocational Education in Food service Services. Various qualifications that become priorities are leadership where leadership is the ability to motivate, guide, and support others to achieve something and have delegate skills (Sail \& Alavi, 2010).

Industry will continue to grow in the 21 st century with a variety of theories that are developing such as industry theory 4.0 (Revee, 2016). Preparation of qualifications in accordance with the needs of the food service industry must be prepared in the form of knowledge and discipline in learning all developments in the industry including leadership. The ability to lead and communicate both formally and informally becomes a big capital for workers in following and fulfilling various qualifications in the industry (D. N. A. Ismail, 2011). A good ability possessed by each worker will be able to help workers survive under the various pressures that exist in the industry and increase work wages ( $R$. Ismail, 2009)

\subsection{Leadership and Vocational Education}

Vocational education is obliged to develop the professionalism and leadership of their students so that they are able to meet industry qualifications and compete in them (Gehlhar, Regmi, Stefanou, \& Zoumas, 2009). It aims to achieve the goal of vocational education itself in preparing competent students according to industry needs (Hagos \& van, 2013; Olander \& Olander, 2013).

Leadership in theory is called a behavior which is able to provide participatory, distributive and democratic and able to organize effectively in carrying out transformations and changes (Anne, 2015; Reeve, 2016). In general, such leadership is the most effective for vocational education (Callan, Mitchell, Clayton \& Smith, 2007; Eddy, 2010; Nevarez, Wood \& Penrose, 2013; Vargas, 2013).

Leadership has strength in every job well in working with colleagues, this is what helps vocational education students in entering the workforce with various demands. This leadership is considered capable and very closely related in the management process of a job that is visionary and directed because workers who have good leadership will be able to capture instructions, organize and carry out it according to the direction of achieving 
Table 1. Leaderships Importance

Robertson, 2015).

\subsection{Leadership in Food and Service Education}

Having leadership above the average for workers in the food service industry is becoming increasingly important. In the food service industry, having the ability to organize work, the ability to see and make a strategy in achieving goals are key in a job. The leadership characteristics that must be possessed by workers in the food service industry (Ronald and Michael, 1990) are as follows:

a. The ability to share tasks according to the duties of each worker

b. Have a high energy

c. Have an oriented

d. Able to fulfil every job demand and share and transform information about work.

Being a leader for every worker besides paying attention to the characteristics of leadership of the workers, there are several competencies from the leadership values that must be possessed by workers in the food service industry such as:

a. Have full attention in carrying out their duties and work.

b. Having the ability to communicate as a leader in transforming information to all team members.

c. Having the ability of reliability, predictability and accountability in work.

d. Have the ability to be confident in facing various failures and work problems properly.

e. Have the ability to develop a vision in achieving organizational or workplace goals.

f. Have trust in team members or other workers in coordinating the process of carrying out the work.

g. Have special abilities or expertise in the field

h. Have the ability to carry out tasks.

i. Have a good focus on seeing the expectations and reality of work in the food service industry.

j. Have job loyalty in the work environment.

k. Have good competitiveness.

Many previous studies have mentioned that leadership is not something absolute. But it will be very relative to the sharpness of each person's personality. The importance of leadership in a job that can be adapted to the needs of the food service industry can be seen in table 1 : Competences

\begin{tabular}{l}
\hline \multicolumn{1}{c}{ Competences } \\
\hline Effective Leaders \\
\hline Personal who is strong and has high trust values \\
\hline Able to provide information by going up \\
\hline Able to listen and speak well with other workers. \\
\hline Know the strength of each team member / worker \\
\hline Become a source of "power" for other workers. \\
\hline Leaderships Keys \\
\hline Vision development \\
\hline Expert in their field \\
\hline Dare to take risks \\
\hline Have trust in coordination \\
\hline Leader's necessity \\
\hline High credibility \\
\hline High accountability \\
\hline Competitive \\
\hline Serve \\
\hline Empathy \\
\hline Good physical and emotional stamina \\
\hline Ability to anticipate. \\
\hline
\end{tabular}

From table 1, a number of leadership competency values that must be possessed by every food service worker, where a food service industry requires workers to be able to provide excellent, effective and efficient service to provide satisfaction to consumers. In addition to the various competencies that must be owned by food workers, a worker who has good leadership must be able to continue learning to develop various competencies in every process of work undertaken. Because in this industrial world changes continue to occur dynamically and cannot be predicted. This industrial era 4.0 puts forward digital automation including the involvement of robots. However, social skills cannot be possessed by robots, including leadership, which is a priority for food service industry workers in supporting various solutions to the challenges that exist in the civil service. So, this competition must be won by workers compared to robots including in leading work for workers in the food service industry.

\section{CONLUSIONS}

Workers will be demanded for various competencies that must be completed in order to fulfil the food service industry qualifications. Excellent service is the main focus in achieving the goal of giving satisfaction to the waiter. Every worker must have good leadership in the midst of the various demands 
and challenges of employment in the food service industry both physically, socially and emotionally. This leadership becomes an answer to the problems of various challenges that exist in this industrial era 4.0 , because through this leadership has the ability to work effectively, efficiently, collaboratively, innovatively and excellently.

\section{ACKNOWLEDGMENTS}

The researcher thanks God Almighty because thanks to His mercy, researchers were able to finish writing this research well. In addition, the researcher thanked each member of this research writing team Ana A., Vina Dwiyanti, Ellis Endang Nikmawati, Sri Subekti and Dewi Eka Murniati who had collaborated well in the completion of this research writing. As well as to the entire UPI extended family as an institution where the authors take shelter and forge themselves with various sciences so that they can finish writing well as well as the entire family of their respective researchers who have provided moral assistance and provide great support.

The researcher thanked the previous researchers who had the same research theme and / or according to the needs of the researchers in completing the writing of this study, so as to assist the author in enriching the reference of the research conducted. The researcher hopes that there will be benefits in writing this research, especially for the school of vocational education and students in preparing themselves for real competition in the era of industry 4.0 with various demands of the 21 st century that continue to grow based on the suitability of the needs of the food service industry.

\section{REFERENCES}

Anne, C. (2015). Leadership development for technical and vocational education and training college leaders in South Africa: a post-graduate curriculum framework.

Bauer, W., Hämmerle, M., Schlund, S., \& Vocke, C. (2015). Transforming to a Hyper-connected Society and Economy-Towards an "Industry 4.0.". Procedia Manufacturing, 3, 417-424.

Callan, V., Mitchell, J., Clayton, B \& Smith, L. (2007). Approaches for sustaining and building management and leadership capability in VET providers. NCVER Adelaide, 1-42.

Catherine A., and Robertson. (2015). Leadership Development for Technical and Vocational Education and Training College Leaders in South Africa Post Graduate Curiculum Framework. Stellenbosch University.
Cichy, R.F. and Cook, C.L. (1991). Leadership Qualities: The Non-Commercial Food Service Industry. Restaurant Personnel Management, 4 (8), 6-7.

Cichy, R.F., and Michael, S. (1990). Do You Fit This Profile of a Hospitality Leader? Lodging, 15 (10), 4042.

Cichy, R.F., Cook, C.L., Sciarini, M.P., and Patton, M. (1991). Leadership in the Lodging and NonCommercial Food Service Industries. FIU Hospitality Review, 9 (10), 1-10.

Costa, C., Bakas, F. E., Breda, Z., Durão, M., Carvalho, I., \& Caçador, S. (2017). Gender, flexibility and the ideal tourism worker. Annals of Tourism Research, 64, 6475.

Gehlhar, M. J., Regmi, A., Stefanou, S. E., \& Zoumas, B. L. (2009). Brand leadership and product innovation as firm strategies in global food markets. Journal of Product and Brand Management, 18 (2), 115-126.

Gerald, (2014). Kesiapan SDM Pariwisata di Indonesia, Buletin Kementerian Pariwisata Dan Ekonomi Kreatif.

Hagos Baraki, A., \& van Kemenade, E. (2013). Effectiveness of Technical and Vocational Education and Training (TVET). The TQM Journal, 25 (5), 492 506.

Ismail, D. N. A. (2011). Graduates' Characteristics and Unemployment: A Study Among Malaysian Graduates Associate Professor Dr . Noor Azina Ismail Department of Applied Statistics Faculty of Economics and Administration University of Malaya 50603 Kuala Lumpur, Malaysia. Journal of Business and Social Science, 2 (16), 94-103.

Ismail, R. (2009). Technical efficiency, technical change and demand for skills in Malaysian food-based industry. European Journal of Social Sciences, 9 (3), 504-515.

Mersha, T., \& Adlakha, V. (1992). International Journal of Service Industry Management Article information: International Journal of Service Industry Management, 3 (3), 34-45.

Nevarez, C, Wood, J L and Penrose, R. (2013). Leadership theory and the Community College. Stylus. Virginia USA.

Olander, C., \& Olander, M. H. (2013). Professional Development through the Use of Learning Study: Contributions to Pedagogical Content Knowledge in Biology. Procedia-Social and Behavioral Sciences, 89, 205-212.

Qin, J., Liu, Y., \& Grosvenor, R. (2016). A Categorical Framework of Manufacturing for Industry 4.0 and beyond. Procedia CIRP, 52, 173-178.

Ramle, M., \& Rohana, R. (2012). Integration of social skills and social values in the National Dual Training System (NDTS) in the Malaysian automotive sector: employers ' perspective. Proceedings of the 2nd UPI International Conference on Technical and Vocational Education and Training Bandung, Indonesia, 2 (1), 133-143.

Reeve, E. M. (2016). 21 ${ }^{\text {st }}$ Century Skills Needed By Students in Technical and Vocational Education and Training. Asian International Journal of Social 
Sciences, 16 (4), 65-82.

Sail, R. M., \& Alavi, K. (2010). Social skills and social values training for future $\mathrm{k}$-workers. Journal of European Industrial Training. 34.

Sanders, A., Elangeswaran, C., \& Wulfsberg, J. (2016). Industry 4.0 implies lean manufacturing: Research activities in industry 4.0 function as enablers for lean manufacturing. Journal of Industrial Engineering and Management, 9 (3), 811-833.

Vargas, J G. (2013). Creating a new university-based community college leadership program. Community College. Journal of Research and Practice, 37 (6), 478-489. 